\section{Migração e Geografia}

\author{
Eduardo Marandola Jr. *
}

SPOSITO, Eliseu S.; BOMTEMPO, Denise C.; SOUSA, Adriano A. (Orgs.). Geografia e migração: movimentos, territórios e territorialidades. São Paulo: Expressão Popular, 2010. 304p.

A Geografia tem oferecido uma contribuição perene aos estudos migratórios, especialmente na discussão sobre as dimensões espaciais da migração, as quais envolvem tanto os processos territoriais de expulsão de populações (origem dos fluxos), quanto a absorção de fluxos e as transformações espaciais no local de destino. Estes processos têm sido vistos, mais recentemente, em termos de desterritorialização e reterritorialização, incorporando às análises as relações de poder envolvidas em todo o processo migratório. Mais do que isso, pensar a migração a partir deste enfoque tem permitido entendê-la, do ponto de vista do sujeito em trânsito, enquanto processo de articulação de dois territórios diferentes (origem e destino), em sua dimensão relacional, dando origem às análises sobre multiterritorialidade, extraterritorialidade e interterritorialidades.

O livro Geografia e migração: movimentos, territórios e territorialidades, organizado por Eliseu Savério Sposito, Denise Cristina Bomtempo e Adriano Amaro de Sousa, da Universidade Estadual Paulista (Presidente Prudente), é um bom exemplo destas contribuições que a Geografia tem dado para os estudos migratórios, colocando a dimensão do território no centro da análise.

O livro se coloca ainda como repercussão do centenário da imigração japonesa para o Brasil, comemorada em 2008, contendo um conjunto de contribuições e reflexões que enfocam este fluxo migratório em suas duas principais facetas: as territorialidades dos imigrantes em diferentes regiões do Brasil (especialmente São Paulo e Paraná); e os processos e problemáticas que envolvem a migração dos descendentes para o Japão, os conhecidos dekasseguis. Estes dois pontos são abordados por um conjunto heterogêneo de autores (não necessariamente geógrafos), entre os quais se encontram experientes pesquisadores do tema, alguns com várias décadas dedicadas ao estudo destes fenômenos, e alguns jovens pesquisadores (cursando mestrados e doutorados).

Tendo isso em vista, além da necessidade de refletir sobre as novas questões pertinentes ao fenômeno na atualidade, o livro está organizado em três partes.

\section{Parte I - Geografia e migração: questões teórico-metodológicas}

- Paradoxos do lugar mundo: brasileiros e identidades, Jones Dari Goettert

- Imigração japonesa e produção de "entrelugares": uma contribuição para o debate sobre identidade, Marcelo Alario Ennes

- Lugar, sonhos e migração: uma leitura dos movimentos migratórios entre Japão e Brasil, Denise Cristina Bomtempo, Eliseu Savério Sposito

- O discurso sobre a imigração chinesa para o Brasil, Marilena dos Santos Ferreira de Castilho

- O(s) tempo(s) e o(s) território(s) da imigração do sul do Brasil, Marcos Aurélio Saquet

\section{Parte II - A territorialidade dos japoneses e descendentes no Brasil}

- Entre os sonhos e a realidade: reflexões, Célia Sakurai

\footnotetext{
* Geógrafo, Núcleo de Estudos de População, Universidade Estadual de Campinas - Nepo/Unicamp.
} 
- Nipo-brasileiros na teicultura: territorialização e monopolização do território, Ruth Youko Tsukamoto

- A dimensão geo-histórica do industrial nipo-brasileiro no contexto do oeste paulista, Adriano Amaro de Sousa

- Um novo mundo (re)fundado. Imigrantes japoneses no norte paranaense, Alice Yatiyo Asari

\section{Parte III - Inversão dos destinos: a migração dos brasileiros para o Japão}

- Identidade e paisagem: o enraizamento dos dekasseguis do Brasil no Japão, Rosa Ester Rossini

- Redes sociais e migrações laborais: múltiplas territorialidades. A comunidade nipo-brasileira de Ourinhos (SP), Lirian Melchior

- Os trabalhadores dekasseguis e a tragédia da reestruturação produtiva, Fábio Kazuo Ocada

- Os imigrantes brasileiros no meio técnico científico informacional japonês, Ricardo Hirata Ferreira

As partes dois e três refletem as principais contribuições que a Geografia tem dado para os estudos migratórios, especialmente no que se refere ao estudo da migração japonesa, tanto em suas repercussões no Brasil quanto nas implicações e problemáticas relacionadas ao fluxo dos dekasseguis. Este talvez seja o tema que tem tido a mais perene atenção por parte dos geógrafos.

O mesmo talvez não se possa dizer da primeira parte, dedicada a questões teórico-metodológicas, a partir da Geografia. Talvez não seja exagero dizer que a ciência geográfica, em seu conjunto, ainda deve uma contribuição mais sistemática à teoria da migração, especialmente nas últimas décadas de tantas transformações na forma de produção e organização espacial no mundo. E esta dívida é apenas em parte saldada pelos cinco ensaios que compõem a primeira parte do livro. Gostaria de destacar três pontos a este respeito.

1. Os textos têm o mérito de buscar nas ideias de lugar e território a dimensão geográfica do processo migratório, fazendo-o em termos da produção e reprodução social (lugar) e das relações de poder e apropriação (material e simbólica) nos locais de destino (território). Procuram ainda colocar a discussão da mobilidade e fluidez contemporânea associada aos entrelugares e territórios móveis. Sem dúvida, esta tem sido uma contribuição teórica importante nas últimas duas décadas.

2. No entanto, a presença de uma teoria geográfica nos textos se alterna, tanto pela perspectiva dos autores quanto pela ausência de um diálogo mais direto com uma epistemologia geográfica. Isso não enfraquece os textos em si, mas mantém a lacuna coletiva dos geógrafos em conseguir contribuir teoricamente para os estudos migratórios de forma mais sistemática.

3. Por fim, trazer elementos oriundos da própria empiria ajuda a tornar as questões teóricas levantadas mais aderentes ao mundo contemporâneo. No entanto, o alcance pode ficar limitado, na medida em que dependemos de análises realizadas no seio de abordagens que tendem a compreender a questão da territorialização e da espacialidade como metáfora, e não como materialidade produzida e experiencialmente vivida.

Geografia e migração: movimentos, territórios e territorialidades é um belo livro sobre os processos migratórios contemporâneos que ajuda a levantar e problematizar estas questões, especialmente aquelas relacionadas aos fluxos Japão-Brasil e Brasil-Japão, mostrando uma consolidação destas investigações. O livro aponta alguns caminhos para uma contribuição mais efetiva da teoria geográfica para o conjunto dos estudos migratórios contemporâneos, mas ainda há outros que podem ajudar a ampliar o escopo das análises e das possibilidades de investigação.

Talvez a principal colaboração da Geografia para os estudos migratórios 
seja incorporar a dimensão espacial no processo de forma orgânica, ou seja, como parte essencial do fenômeno. Isso implica potencializar o significado do território e dos processos de territorialização, bem como de envolvimento com lugar, para além de seus usos metafóricos, que acabam por enfraquecê-los enquanto discursos pas- sageiros ou manipuláveis. Para além da questão ideológica, a resistência material e os significados simbólicos do espaço se impõem e, por isso, a discussão interdisciplinar precisa avançar no sentido de pensar as categorias espaciais enquanto reveladoras das dinâmicas sociais, econômicas, políticas, culturais e demográficas da migração.

Recebido para publicação em 03/11/2010 Aceito para publicação em 06/11/2010 